\title{
Conservation and species lists: taxonomic neglect promotes the extinction of endemic birds, as exemplified by taxa from eastern Atlantic islands
}

\author{
C. J. HAZEVOET
}

\section{Summary}

When formulating conservation priorities, conservation biologists often rely on published lists of species-level taxa. This paper discusses the nature and taxonomic status of "species" and "subspecies" and different ways of defining "species". Species are here taken to be terminal and evolutionarily independent units which are qualitatively diagnosable and reproductively cohesive; genealogical biodiversity is thus taken for what it is in the first place, namely the observable result of evolutionary history, an approach which has become known as the phylogenetic species concept (PSC). In contrast to the widely applied Mayrian or "biological" species concept (BSC), no inferences are made about how the degree of morphological differentiation of allopatric but seemingly closely related taxa translates in the absence or presence of reproductive isolation. Many diagnosably distinct endemic island taxa have traditionally been treated as "subspecies" of widespread "polytypic biological" species. At the same time, the "subspecies" category is also used to name arbitrarily delimited sections of intraspecific clinal variation. Thus, the "subspecies" category subjects entirely different evolutionary phenomena to the same hierarchical level through the use of trinomials. Nevertheless, and despite the discrepancy in ontological status among its contents, "subspecies" are usually considered to be of lower evolutionary and/or conservation status than "species" and this has resulted in low conservation priorities allotted to diagnosably distinct island endemics, many of which have traditionally been considered to be "merely Mayrian subspecies". This has been recognized by some authorities who, because of the threatened status of certain island taxa, advocated treating them binomially in order to generate appropriate conservation measures to save them from extinction, without however justifying their action by any sort of phylogenetic reasoning. Although well intended and sometimes quite successful as regards the follow-up by conservationists, this demonstrates the arbitrary manner in which "species" can be defined under the BSC. Some examples of endemic taxa from eastern Atlantic islands are discussed, demonstrating the way "list thinking" and the lack of phylogenetic reasoning among conservationists translates into the presence or absence of conservation actions. Some of the criticisms of the PSC by adherents of the BSC are discussed. It is advocated that conservationists replace "list thinking" with "lineage thinking". 


\section{Introduction}

It is now generally recognized that, as a result of human activities, biological diversity on this planet is in a state of crisis and that well-planned and worldwide conservation actions are urgently needed to safeguard a wide range of plant and animal taxa. When formulating conservation priorities, conservation biologists often rely heavily on published lists of species and the distributional data given therein. Indeed, an increasing number of Red Lists are being published with the explicit purpose of providing a base line for conservation actions. Because their distribution and taxonomy are relatively well known, birds are often taken as good indicators of overall biodiversity and an attempt has been made to map their areas of endemism globally (ICBP 1992). An updated world list of threatened birds has also recently been published (Collar et al. 1994). Both the mapping and the listing involve species-level taxa. Because both works were published by a major conservation organization and are intended to provide basic information for decision-makers in conservation biology, their contents will generally be assumed to be authoritative. Still, we may ask what the species taxa mentioned in these and similar works actually represent and how they were defined.

At this point a distinction must be made between genealogical and ecological diversity (see Eldredge 1992). Ecological diversity is usually taken to mean the number of different kinds of organisms present in a local ecosystem. This is often expressed as the number of species, while, in fact, in most cases only local populations (i.e. portions of species) are present in local ecosystems. Genealogical diversity concerns the number of taxa within a monophyletic clade, e.g. the number of species within a genus. The present paper is concerned with genealogical diversity.

During the last few decades, there have been surging discussions in the systematics community about the nature of species-level taxa and how these should be delimited. Most of this growing literature has been published in specialist journals and books, and much of it has apparently gone quite unnoticed by workers in biological disciplines other than systematics, including conservation biology. Moreover, the representation of the species concept debate in much of the ornithological literature has been inadequate, probably leaving the non-specialist reader at a loss as to what the argument is all about. Yet there is much at stake because the entire theoretical and empirical structure of comparative biology depends on how species (and other taxa) are conceived (Nelson 1989). With few exceptions (e.g. Rojas 1992), the implications of different concepts of species for conservation biology have been well-nigh neglected by conservation biologists, although their activities are thoroughly affected by the way species are defined.

In this paper, the nature and taxonomic status of "species" and "subspecies" is addressed, as well as the use of species lists in relation to the conservation of existing biodiversity. The position taken herein is that species are terminal and evolutionarily independent units which are qualitatively diagnosable and reproductively cohesive; they are the basic taxon in the hierarchy of nature. Species are also the units considered for preservation by decision-makers in conservation biology and, as such, they are the units employed in conservation 
legislation. This will be illustrated with examples of threatened endemic bird taxa from eastern Atlantic islands, which have, however, not been rated at their true value (i.e. they have traditionally been considered to be "merely subspecies") and which consequently may now face extinction.

\section{Different concepts of species}

Various species concepts have been formulated during recent decades (for reviews see Cracraft 1989b, Templeton 1989, Sluys 1991, O'Hara 1993) but it seems fair to say that during much of this century the Mayrian or "biological" species concept (hereafter BSC) has been the dominant one. Originally formulated by Mayr (1940, 1942) at the time of the "Modern Synthesis" of the 1930 s and 1940s, it remained almost unchallenged - at least in ornithology until the early 1980s. Although different and amended versions have appeared over the years, the core dictum of the BSC appears to be that species are "groups of interbreeding natural populations that are reproductively isolated from one another." A clause on "potential interbreeding", which appeared in the original wording, has been dropped from most later versions (but not all, e.g. AOU 1983). A notion of the "potential" ability to interbreed is, however, always implicit in the way the BSC is applied, this being most apparent in the "intuitive" manner in which taxonomically differentiated allopatric taxa are classified as either "species" or "subspecies". A crude version of the BSC has been put forward by ICBP (1992): "a species is a group of organisms capable of breeding freely with each other but not with members of other species". This wording is so vague that it will indeed be hard to apply in any natural situation, and in fact it amounts to circular reasoning.

A fundamental shift in outlook concerning the role of the concept of evolution in taxonomy has taken place since the rise of phylogenetic systematics (cladistics) following the publication of the English edition of the late Willi Hennig's work in 1966. Because the use of "biological" species can cause serious flaws in the reconstruction of the phylogeny and historical biogeography of species-level taxa, systematists have become increasingly discontented with the BSC (for discussions by workers on various taxonomic groups, see Cracraft 1983, 1986, 1989a, 1992, Donoghue 1985, Mishler and Brandon 1987, McKitrick and Zink 1988, Lidén and Oxelman 1989, Echelle 1990, Frost and Hillis 1990, Devillers and Devillers-Terschuren 1994). A recurrent problem in the application of the BSC is that the degree of reproductive isolation of taxonomically differentiated, allopatric and seemingly closely related taxa cannot be verified. Therefore, when allocating taxa as either "species" or "subspecies", the BSC relies heavily on subjective or statistical inferences whether allopatric taxa have diversified "sufficiently" in their morphology and/or genetics as a substitute measurement of reproductive isolation. Judgements on the degree of reproductive isolation in allopatric populations force taxonomists to speculate about what may or may not happen at some time in the future. Obviously, this amounts to acts of faith rather than fact (Crowe 1993) and indeed some adherents of the BSC have stressed their religious tenor. Thus, Amadon and Short (1992) found that species are those organisms "which Noah, loading his Ark, called species". 
Clearly, it is hard to argue against such a belief, but still a more objective and verifiable approach seems warranted.

It has been persistently argued by various authors (e.g. Cracraft 1983, 1989a, McKitrick and Zink 1988, Hazevoet 1994a) that reproductive isolation is not the cause of biological diversification but rather maintains it. In fact, it only represents one particular autapomorphic (i.e. uniquely derived) character state amongst closely related taxa, i.e. reproductive incompatibility, which may help to diagnose sympatric taxa under any species concept but is, in practice, unworkable for allopatric taxa. Moreover, the retention of the ability to interbreed (a symplesiomorphic - i.e. shared primitive - character state) does not indicate genealogical relationship, i.e. taxa which do form hybrid swarms are not necessarily sister taxa and their hybridizing should not prevent their recognition as independent evolutionary lineages. To add to its half-fledged status, the "subspecies" category to which "insufficiently" differentiated allopatric taxa are relegated is also used to name sections of intraspecific clinal variation and different grades of environmental adaptation (usually based on differences in the means of various quantitative variables and/or minor variations in plumage coloration), which have no ontological status as independent evolutionary taxa. Thus, the "subspecies" category is rendered an almost meaningless wastebasket containing entirely uncomparable evolutionary phenomena which are, however, subjected to the same hierarchical level through the use of trinomials. Additionally, the inclusion of an array of allopatric "subspecies" in one "biological" species does not clarify in the least which of the taxa included (presuming that these are independent and distinct evolutionary entities) are each other's closest relatives, i.e. sister-taxa. It only indicates that these populations are thought to be "somehow" closely related and that it is speculated that they would be reproductively compatible were they ever to come into contact. There is always the potential danger that polytypic "biological" species are actually polyphyletic and, therefore, do not represent real-world entities.

As an alternative to the BSC, Cracraft (1983, 1987, 1989a,b, 1992) proposed a different approach which was coined the phylogenetic species concept (hereafter PSC). Herein, a species is defined as "an irreducible (basal) cluster of individual organisms, diagnosably distinct from other such clusters, and within which there is a parental pattern of ancestry and descent". In practice, this is not significantly different from the wording by Nelson and Platnick (1981), which states that species are "simply the smallest detected samples of self-perpetuating organisms that have unique sets of characters". As is clear from both definitions, these are purely operational and do not include assumptions about how the degree of morphological or genetic difference translates into the presence or absence of reproductive isolation: existing biodiversity is primarily viewed for what it is, namely the observable result of evolutionary history. One of the pivotal arguments for this approach is that theories on processes which may or may not have given rise to the observed pattern of evolutionary diversification can only be tested when that pattern is recognized without assumptions about those processes. The BSC follows exactly the opposite course by recognizing pattern through assumptions of process, thus putting the cart before the horse. Under the PSC, data on reproductive 
behaviour may also be used to delimit species-level taxa but this will concern data on the reproductive cohesiveness of populations rather than speculation about the degree of reproductive isolation of allopatric taxa. The importance of reproductive cohesiveness has also been stressed under some of the BSC's derivatives, e.g. the recognition concept of species (Paterson 1985).

Under the PSC there will be little, if any, room left for the "subspecies" category because the distinctiveness of (groups of) populations is taken as the essence of species. Although intraspecific geographical variation should be studied, analysed and mapped using all relevant modern methods, this does not require the naming of arbitrary sections of these patterns of variation (see, for example, Zink and Remsen 1986, Ball and Avise 1992). The proper taxonomic framework for counting biological diversity resides with taxa of species rank, not with "subspecies" as required by the BSC (Cracraft 1992), and the PSC helps to remove the traditional ambiguity towards differentiated allopatric taxa.

Another aspect of the "subspecies" category, which may perhaps seem quite obvious but appears not always to be fully appreciated, concerns a linguistic issue. It is common usage to speak of taxon A as being a "subspecies" of taxon B, in which case taxon B represents the nominate "subspecies". This may suggest that taxon $B$ is somehow more important than or dominant over taxon A, while, in fact, the designation of nominate "subspecies" is merely a nomenclatural matter (i.e. the particular taxon in a polytypic "biological" species which was first named) and this does not have any biological or evolutionary significance whatsoever. All "subspecies" of a polytypic "biological" species (including the nominate one) are of equal rank and importance relative to each other, yet there often seems to exist a tendency in conservation biology to allot higher value to the nominate "subspecies" than to "subspecies" which were accidentally named at some later date.

Recently, the PSC has been elaborated in considerable detail by Nixon and Wheeler (1990) and Davis and Nixon (1992), and it has become the species concept of choice in many contemporary ornithological studies on the systematics and historical biogeography of species-level taxa (e.g. Cracraft 1986, 1989a, 1992, Zink 1986, 1988, 1994, Siegel-Causey 1988, Livezey 1990, 1991, $1995 a, b)$.

\section{Species lists, species concepts and conservation}

The database for conservation action will usually be extracted from various local or regional inventories of species occurring in different areas. A quick glance through recent bird conservation papers shows that these abound in statements in which the number of species occurring in one area is compared with that occurring in another area. Apparently, this is often taken as a measure of species richness as well as an index of overall biodiversity. "Biodiversity" is thus taken in the sense of ecological diversity (see above). Remsen (1994) pointed out that many local and regional species lists are unsuitable for making comparisons between areas because of various differences and flaws in methodology which render doubtful their usefulness for community ecology and conservation. Moreover, direct comparisons of lists can be dangerous because of various complicating factors, such as the different ecological diversities included in the 
inventories. Apart from such methodological problems, it is often unclear what is the ontological status of the "species" included in such lists. In most cases, species limits will be derived from popular field guides or other regional works. Such sources, however, have usually not been designed to offer a very precise view of real-world biodiversity and normally only list generalized "biological" species. In the case of "polytypic biological" species, the reader is thus left uninformed whether the local representatives of those species belong to differentiated and independent evolutionary lineages or constitute an arbitrary segment of a more general pattern of clinal variation.

Recently, the notion that "accepted" taxonomy should not automatically be taken for granted when dealing with conservation issues has become more apparent (e.g. Daugherty et al. 1990, May 1990, Crowe and Siegfried 1993, Crowe et al. 1994, Prum 1994), and Daugherty and Triggs (1991) have stressed the necessity for basing conservation practice on accurate taxonomies. Blindly accepting traditional taxonomy may well lead to the neglect and even extinction of distinct but spatially restricted endemic taxa which, however, suffer from a low standing because they are considered to be "merely subspecies".

\section{Endemic taxa from eastern Atlantic islands}

To understand better the consequences of an approach in conservation biology based on traditional listings of "biological" species, the conservation effort bestowed on different endemic taxa from the eastern Atlantic islands will be considered. In the Cape Verde Islands, 26 taxa have been described from specimens collected there. Two of these (Raso Lark Alauda razae and Cape Verde Warbler Acrocephalus brevipennis) have traditionally been treated unequivocally as monotypic endemic species, while a third (Brown-necked Raven Corvus ruficollis) is a widespread species which is of no further concern here. Four taxa have at times been treated as either endemic species or subspecies, i.e. Cape Verde Petrel Pterodroma feae, Cape Verde Shearwater Calonectris edwardsii, Cape Verde Swift Apus alexandri and Iago Sparrow Passer iagoensis (the case of $P$. feae is, in fact, somewhat more complicated, as will be discussed below). The remaining 19 taxa have traditionally been treated as subspecies of widespread "polytypic biological" species.

With the aim of distinguishing unique evolutionary lineages among the birds of the Cape Verde Islands, Hazevoet (1995) studied a large number of specimens in major museum collections, while lengthy field studies were conducted in the islands during which live birds of several taxa were examined in the hand. Based on qualitative character variation within and between populations, 14 phylogenetic species endemic to the Cape Verde Islands were postulated, including the six taxa mentioned above (for diagnoses, see Hazevoet 1995). In the remaining 11 taxa, traditionally treated as subspecies confined to the islands, no diagnostic morphological characters could be identified which would justify their recognition as phylogenetic species.

It should be emphasized that the 14 endemic taxa of the Cape Verdes each represent a unique and independent evolutionary lineage. Of these 14 taxa, eight are threatened or, at least, vulnerable. The total population of some only 
reaches some tens of pairs (e.g. Cape Verde Purple Heron Ardea bournei, Cape Verde Kite Milvus fasciicauda, Cape Verde Buzzard Buteo bannermani, Cape Verde Peregrine Falco madens), while others are extremely restricted spatially, with a total population of only a few hundred, e.g. Alauda razae and Acrocephalus brevipennis (for population estimates, see Hazevoet 1989, 1992, 1993, 1994b, 1995). Only three of these taxa are included in the main section of the "Official Source for Birds on the IUCN Red List" (Collar et al. 1994), i.e. Pterodroma feae, Alauda razae and Acrocephalus brevipennis. Four others are mentioned in a list of "threatened subspecies which may be valid species" i.e. Arden bournei, Milvus fasciicauda, Buteo bannermani, Falco madens), but no criteria were provided indicating along which line of reasoning such "valid species" may eventually be recognized. The often used but meaningless term "full species" - apparently an equivalent of "valid species" - is employed in the same list. One threatened taxon (Calonectris edwardsii) is not mentioned at all by Collar et al. (1994). Probably, the sole criterion used by Collar et al. (1994) to recognize so-called "valid species" is not phylogenetic reasoning but merely "authority", a phenomenon that has already plagued avian systematics for many decades (see Raikow 1985). To some extent this may be inevitable but it sheds light on the arbitrary nature of the taxa included in such Red Lists, which may be recognized for completely different and uncomparable lines of reasoning.

The taxonomic history of the eastern Atlantic gadfly petrels in the Pterodroma mollis species-group (feae of the Cape Verdes, deserta of the Desertas islets off Madeira, madeira of mainland Madeira) provides a particularly illustrative example. Although $P$. feae enjoyed the status of a "distinct species" when it was first described from a Cape Verde specimen (Salvadori 1899), it was subsequently reduced to "subspecies" rank (Mathews 1934), and it almost ended its evolutionary career as a "dubious race" (Bourne 1983). Needless to say that in the meantime nothing had changed regarding the real-world ontological status of the taxon. Bourne (1983) called attention to the discrepancy in conservation effort accorded to the rare and presumably closely related $P$. cahow from Bermuda and the equally rare and endangered taxa of the eastern Atlantic islands, apparently because of the low taxonomic status of the latter. Although Bourne (1983) displayed only a rudimentary form of phylogenetic reasoning, he stressed that the eastern Atlantic taxa "are in fact sympatric [sic] forms of great interest which are in grave danger". Bourne's (1983) main motives in advocating "to abandon taxonomic caution" and to treat mollis, feae and madeira binomially were obviously their rarity and his concern about the lack of conservation action. It can indeed be said that Bourne's (1983) paper has been quite successful in this respect and that considerable conservation effort has been given since in order to save the Madeiran Petrel P. madeira from extinction (e.g., Zino and Zino 1986, Zino 1991, Zino and Biscoito 1994), and it has now become common practice to treat feae and madeira as separate ("biological') species. Doubtlessly, feae and madeira represent unique and independent evolutionary lineages and thus merit recognition as phylogenetic species. Further research on deserta (usually considered morphologically indistinguishable from feae but, in view of its strong phylopatry, not unlikely to be distinct in other - e.g. molecular and/ or ethological - characters) is warranted. Well intentioned as Bourne's (1983) 
motives may have been, the point here is that a single and systematically insignificant paper by an "authority" on seabirds apparently suffices to accomplish the acceptance of a taxon as a "valid species" and to generate conservation action (and funds). Such policy has little to do with sound analyses of evolutionary diversification, let alone with an appreciation of the principles of phylogenetic systematics, yet conservation biology appears to be imbued with it.

On the other hand, the same author has been persistent in his opinion that Calonectris edwardsii does not represent a distinct evolutionary lineage but "merely an extreme form of geographical variation of $C$. diomedea" (Bourne 1986, Bourne and Casement 1993). Apparently, this view is based on a rather awkward interpretation of the mean values of various morphometrics (i.e. phenetic data) of edwardsii and its sister taxa diomedea and borealis, disregarding the qualitative character states that distinguish the three taxa involved (see Hazevoet 1995). One of the effects of this type of reasoning has been that raising funds for the conservation of several threatened Cape Verde taxa has proved difficult, the rationale being that these are "merely subspecies" (perhaps even "dubious races", and who would care to save such creatures anyway), and the same probably goes for many island endemics elsewhere. Yet, in a phylogenetic sense, there is no difference between the ontological status of $P$. madeira and $P$. fene and that of the phylogenetic species (including C. edwardsii) recognized by Hazevoet (1995): they all represent unique and taxonomically differentiated lineages evolving independently of each other. Without them, little would be left as witness of the many thousands of years of evolutionary diversification that has taken place in the avifauna of these oceanic islands. Nevertheless, several such taxa in the Cape Verde Islands are now in immediate danger of extinction.

Another striking disparity in treatment of distinct and threatened endemic island taxa concerns the Blue Chaffinch Fringilla teydea of the Canary Islands and the Azores Bullfinch Pyrrhula murina of the Azores. Whereas the former received due attention in both Collar et al. (1994) and Tucker and Heath (1994), the latter is not mentioned in either volume, notwithstanding the fact that it is considerably rarer than $F$. teydea (cf. Bibby et al. 1992). The simple explanation must be that no recent authority has as yet advocated its recognition as a "valid species". Again, however, there can be little doubt that murina represents a unique and independent evolutionary lineage, which developed its distinguishing characters in situ.

Ironically, many of the taxa discussed above were originally described as distinct species, but were sacrificed at times when "lumping" was the fashion of the day, often by amateur taxonomists who did not hold any particular theoretical or empirical view on the role and significance of evolutionary diversification in systematics. At a later date, some were again allotted species rank, apparently mainly because of their threatened status. It should, however, be stressed that taxonomic decisions must always be completely independent of conservation concerns. The integrity and scientific reputation of taxonomists would be at stake if they were influenced in any way by the applications of their decisions. 


\section{Discussion}

Although the purpose of this contribution is not to discuss in detail the relative merits of the PSC (which have been roughly pointed out above and have been thoroughly discussed in papers cited), a few points raised by its critics will be commented upon herein because of their exemplary and recurrent nature. Thus, Short (1993) claimed that application of the PSC "would increase by a factor of 5-10 or more the number of avian species", this being "confusing at best and chaotic at worst". He went on to refer to the Golden Whistler Pachycephala pectoralis, which has "70 or more diagnosable subspecies". However, the detailed work by Galbraith (1956) on P. pectoralis, in which he recognizes 57 subspecies, clearly shows that Short's (1993) assertion is an all too easy simplification of the real situation, because many of the named subspecies are part of clines or constitute secondary contact zones. In fact, a considerable number of names currently employed in the "subspecies" category would most probably not hold as diagnosably distinct phylogenetic species, because they merely represent arbitrarily delimited segments of continuous patterns of intraspecific geographical variation. Besides, as any entomologist would readily confirm, there appears to be no theoretical limit to the number of species. The current trend among adherents of the BSC is towards an increase in "splitting" (Knox 1994) and the notion that unsubstantiated "lumping" of species-level taxa only leads to loss of information is apparently coming to be more widely appreciated (e.g. Olson 1994). The mere practice of "lumping" and "splitting", however, is typical of the arbitrary approach encouraged by the BSC. Although "splitting" practices may bring the number of recognized species somewhat closer to the number which would be recognized if the PSC were to be applied, the fundamental differences in theoretical and philosophical premises between the two species concepts remain.

A more ill-natured, indeed perhaps demagogic, argument used by critics of the PSC is their frequent reference to the intraspecific variability of Homo sapiens, implying that application of the PSC to that taxon would lead to the recognition of different "species" of human (e.g. Amadon and Short 1992, Chylarecki 1993, Short 1993). Apparently, the silent suggestion is that advocates of the PSC are, at least effectively, racists and should therefore not be trusted. However, this completely misses the point because in Homo sapiens patterns of phenotypical differentiation are clearly geographically continuous, clinal and/or environmentally adaptive and could in no way be interpreted as being diagnostic of different phylogenetic species. Indeed, even with the use of molecular datasets it remains well-nigh impossible to construct a resolved human phylogeny (e.g. Maddison et al. 1992).

Another issue often raised concerns the limits of diagnosability. It is argued that the PSC would lead to demes or even individuals being recognized as different "species" when molecular data are used (e.g. Amadon and Short 1992). The argument seems to stem from the expectation of certain population biologists that historical phenomena such as speciation can be explained by a simple extrapolation of microevolutionary processes. However, the PSC's criterion of diagnosability refers, of course, to constant and fixed qualitative characters in populations or groups of populations (taxa). With molecular data, 
sample size and geographical coverage are equally critical as with morphological data. However, several recent molecular studies have brought to light morphologically identical or nearly identical species of bird which show substantial molecular differences, suggesting long and separate evolutionary histories (e.g. Capparella 1988, Escalante-Pliego 1991, Zink and Dittmann 1991). In view of this distinctiveness and in recognition of their representing separate lineages, it would only be logical to recognize such cryptic but genetically differentiated taxa as independently evolving taxonomic units, i.e. phylogenetic species. Nothing is gained by insisting that differentiated evolutionary lineages (taxa) nevertheless represent the same thing, regardless of their distinctiveness. This would only lead to loss of information which may be critical to both systematists and conservation biologists.

On the other hand, it has become increasingly clear that genetic variation does often not coincide with the morphological traits on which many traditionally recognized "subspecies" are based. Some may be highly distinct in molecular characters, while in others it is not possible to detect any significant variation (e.g. Barrowclough 1980, Capparella and Lanyon 1985, Ball et al. 1988, Avise and Nelson 1989, Avise and Ball 1991, Ball and Avise 1992). Moreover, there are indications that rearing environment can directly influence the development of some morphological traits on which traditional "subspecies" have been based (James 1983).

Systematists will appreciate that, because of various problems (e.g. insufficient evidence due to limited museum material or inconclusive data), ambiguities may at times be part of applying any species concept and a certain amount of "common sense" is probably also part of any species concept. I concur with Cracraft (1992) that, as long as species limits are seen as hypotheses formulated within the context of available evidence (also part of any species concept), the existence of populations whose status as a terminal taxon is not entirely clear at present should not be particularly disturbing. For instance, most zoologists would probably agree that there exist at present two species of hippopotamus Hippopotamidae, but claiming that there are exactly 319 species of hummingbirds Trochilidae (Sibley and Monroe 1990) seems rather pretentious. Admitting that some situations are not entirely clear should stimulate further research and seems highly preferable to pretending that all problems have been solved when taxa are simply allocated as either "species" or "subspecies". Indeed, the claims of certain "synthetic evolutionists" notwithstanding, studies of intraspecific variation as well as species- (and higher-) level relationships are all still in their infancy (Barrowclough 1992).

Among the few answers formulated by critics of the PSC has been the introduction of a range of terms to distinguish between different types of "species" and "subspecies". Thus, Amadon and Short (1992) expect us to deal with such enigmatic entities as "meso(sub)species", "mega(sub)species", "isospecies", as well as "quasi-monotypic genera", in which, for instance, a "mesosubspecies" is defined as "a subspecies not approaching species status". Moreover, "several mesosubspecies may form one megasubspecies of a megaspecies". I fail to see the advantage of these terms, because it remains unclear how any of them could be applied in an objective manner. Rather, their effect will be an increase of confusion in the ornithological literature. 


\section{Conclusions}

The authors of the "Official Source for Birds on the IUCN Red List" (Collar et al. 1994) have apparently missed the crux of the species concepts debate when they stated that, referring to Morony et al. (1975) and Sibley and Monroe (1990), "the collision between the phylogenetic and biological species concept has deprived the world of a broadly accepted list of bird species", implying that species limits in the latter work are based on the phylogenetic species concept. However, Sibley and Monroe (1990) explicitly stated that they followed the biological species concept and differences in species limits compared with Morony et al. (1975) are only due to a somewhat more liberal degree of "splitting" by the former. The divergent sequential presentation by Sibley and Monroe (1990) only concerns the higher taxa, based on the work of Sibley and Ahlquist (1990), and the inference that the former has anything to do with the PSC presumably merely arose from the use of the word "phylogeny" in the title of the latter work.

Surely, preserving real-world biodiversity is all about preserving evolutionary lineages, and these are exactly what the PSC seeks to recognize. This is not to suggest that application of the PSC will solve the alleged "species problem". As rightfully pointed out by O'Hara $(1993,1994)$, the "species problem" is not so much something to be solved but rather something to get over: the very existence and character of the "species problem" is itself both a consequence of and evidence for the fact of evolution. I suggest that the PSC is particularly valuable for conservation biology because it removes much of the ambiguities that have traditionally surrounded taxonomically distinct allopatric populations of presumably closely related taxa. In practice, this will mean that workers in conservation biology will have to shift more towards "lineage thinking" instead of "list thinking". In fact, the dangers for conservation biology of simplistic interpretations based on the BSC have been recognized even by its greatest advocates (see O'Brien and Mayr 1991). Of course, it can be argued that the PSC is not needed because it will eventually be shown to be impossible to preserve all biodiversity anyway and that, therefore, the BSC suffices as a rough framework. This seems a matter of low expectations about the possibilities of fundraising for conservation actions and the priorities that have consequently to be set, rather than a well-considered biological approach. Without knowledge of the real magnitude of evolutionary diversification it will be difficult to make well-founded decisions on conservation priorities. Under the concept of "biological species", diagnosable, independently evolving and genetically isolated populations are relegated to practical anonymity because trinomina are seldom considered by non-taxonomists in studies of ecological or evolutionary phenomena (Livezey 1990), and this also applies to conservation biology.

Oceanic island ecosystems are a highly significant and unique part of the earth's biota (Loope et al. 1988). Many distinct island forms, however, are considered not worthy of preservation because they are listed as "merely subspecies" under the BSC. These are allowed to go extinct just because they are thought to be of a lower stature than the nominate "subspecies", usually a continental form. Consequently, the genealogical diversity of island biota will be very much impoverished. Without their distinct forms, regardless of the 
taxonomic rank allotted to them, islands will have little more to offer than representatives of widespread taxa - the typical character of island biota, in some sense the clearest manifestation of evolutionary diversification, will be gone.

\section{Acknowledgements}

During the years 1988-1995, my work in the Cape Verde Islands was financially supported by the Netherlands Section of the International Council for Bird Preservation (now BirdLife International), the Netherlands Foundation for International Nature Protection (van Tienhoven Stichting), the J. C. van der Huchtfonds, the Martina de Beukelaarstichting, the Dierenrampenfonds, the Netherlands Society for the Protection of Birds (Vogelbescherming), and the Netherlands Ministry of Agriculture, Nature Management and Fisheries (Directory of Nature Management). In the Cape Verde Islands, working facilities were provided by the Instituto Nacional de Investigação e Desenvolvimento Agrário (formerly Instituto Nacional de Investigação Agrária) and the Ministério de Peixes, Agricultura e Animação Rural (formerly Ministério do Desenvolvimento Rural e Pescas). Comments on earlier versions of this manuscript were provided by M. Lammertink, Dr R. Sluys, and Dr J. Wattel. Final versions were improved by reviews from Dr A. Kemp and Dr A. T. Peterson. Naturally, responsibility for the views expressed herein remains with the author.

\section{References}

Amadon, D. and Short, L. L. (1992) Taxonomy of lower categories - suggested guidelines. Bull. Brit. Orn. Club 112A: 11-38.

AOU (1983) Check-list of North American birds. Sixth edition. American Ornithologists' Union.

Avise, J. C. and Ball, R. M. (1991) Mitochondrial DNA and avian microevolution. Pp.514524 in B. D. Bell, ed. Acta XX Congressus Internationalis Ornithologici. Wellington, N.Z.: New Zealand Ornithological Congress Trust Board.

Avise, J. C. and Nelson, W. S. (1989) Molecular genetic relationships of the extinct Dusky Seaside Sparrow. Science 243: 646-648.

Ball, R. M. and Avise, J. C. (1992) Mitochondrial DNA phylogeographic differentiation among avian populations and the evolutionary significance of subspecies. Auk 109: 626-636.

Ball, R. M., James, F. C., Freeman, S., Bermingham, E. and Avise, J. C. (1988) Phylogeographic population structure of Red-winged Blackbirds assessed by mitochondrial DNA. Proc. Natn. Acad. Sci. 85: 1558-1562.

Barrowclough, G. F. (1980) Genetic and phenotypic differentiation in a wood warbler (genus Dendroica) hybrid zone. Auk 97: 655-668.

Barrowclough, G. F. (1992) Systematics, biodiversity, and conservation biology. Pp.121143 in N. Eldredge, ed. Systematics, ecology, and the biodiversity crisis. New York: Columbia University Press.

Bibby, C. J., Charlton, T. D. and Ramos, J. (1992) Studies of West Palearctic birds 191: Azores Bullfinch. Brit. Birds 85: 677-680.

Bourne, W. R. P. (1983) The Soft-plumaged Petrel, the Gon-gon and the Freira, Pterodroma mollis, P. feae and P. madeira. Bull. Brit. Orn. Club 103: 52-58. 
Bourne, W. R. P. (1986) Recent work on the origin and suppression of bird species in the Cape Verde Islands, especially the shearwaters, the herons, the kites and the sparrows. Bull. Brit. Orn. Club 106: 163-170.

Bourne, W. R. P. and Casement, M. B. (1993) RNBWS checklist of seabirds. Sea Swallow 42: 16-27.

Capparella, A. P. (1988) Genetic variation in Neotropical birds: implications for the speciation process. Pp.1658-1664 in H. Ouellet, ed. Acta XIX Congressus Internationalis Ornithologici. Ottawa: University of Ottawa Press.

Capparella, A. P. and Lanyon, S. M. (1985) Biochemical and morphometric analyses of sympatric, neotropical, sibling species Mionectes macconelli, and M. oleagineus. Pp.347355 in P. A. Buckley, M. S. Foster, E. S. Morton, R. S. Ridgely and F. G. Buckley, eds. Neotropical ornithology. Washington D.C.: American Ornithologists' Union (Orn. Monogr. 36).

Chylarecki, P. (1993) New Herring Gull taxonomy. Brit. Birds 86: 316-319.

Collar, N. J., Crosby, M. J. and Stattersfield, A. J. (1994) Birds to watch 2: the world list of threatened birds. Cambridge, U.K.: BirdLife International (BirdLife Conserv. Ser. 4).

Cracraft, J. (1983) Species concepts and speciation analysis, Current Orn. 1: 159-187.

Cracraft, J. (1986) Origin and evolution of continental biotas: speciation and historical congruence within the Australian avifauna. Evolution 40: 977-996.

Cracraft, J. (1987) Species concepts and the ontology of evolution. Biol. Philos. 2: 329346.

Cracraft, J. (1989a) Speciation and its ontology: the empirical consequences of alternative species concepts for understanding patterns and processes of differentiation. Pp.2859 in D. Otte and J. A. Endler, eds. Speciation and its consequences. Sunderland, Mass.: Sinauer Associates.

Cracraft, J. (1989b) Species as entities of biological theory. Pp.31-52 in M. Ruse, ed. What the philosophy of biology is. Dordrecht: Kluwer.

Cracraft, J. (1992) The species of the birds-of-paradise (Paradisaeidae): applying the phylogenetic species concept to a complex pattern of diversification. Cladistics 8: 1-43.

Crowe, T. M. (1993) Species as units of evolution, classification and conservation. Pp.1719 in R. T. Wilson, ed. Birds and the African environment: Proceedings of the Eighth PanAfrican Ornithological Congress. Tervuren: Musée Royal de l'Afrique Centrale (Ann. Mus. R. Afr. Centr. [Zool.] 268).

Crowe, T. M., Essop, M. F., Allan, D. G., Brooke, R. K. and Komen, J. (1994) 'Overlooked' units of comparative and conservation biology: a case study of a small African bustard, the Black Korhaan Eupodotis afra. Ibis 136: 166-175.

Crowe, T. M. and Siegfried, W. R. (1993) A southern African perspective of conservation biology. Pp. 285-286 in R. T. Wilson, ed. Birds and the African environment: Proceedings of the Eighth Pan-African Ornithological Congress. Tervuren: Musée Royal de l'Afrique Centrale (Ann. Mus. R. Afr. Centr. [Zool.] 268).

Daugherty, C. H., Cree, A., Hay, J. M. and Thompson, M. B. (1990) Neglected taxonomy and continuing extinctions of tuatara (Sphenodon). Nature 347: 177-179.

Daugherty, C. H. and Triggs, S. J. (1991) Population differentiation in New Zealand birds. Pp. 525-533 in B. D. Bell, ed. Acta XX Congressus Internationalis Ornithologici. Wellington, N.Z.: New Zealand Ornithological Congress Trust Board.

Davis, J. I. and Nixon, K. C. (1992) Populations, genetic variation, and the delimitation of phylogenetic species. Syst. Biol. 41: 421-435.

Devillers, P. and Devillers-Terschuren, J. (1994) Essai d'analyse systématique du genre Ophrys. Nat. Belges (Orchid. 7, Suppl.) 75: 273-400.

Donoghue, M. J. (1985) A critique of the biological species concept and recommendations for a phylogenetic alternative. Bryologist 88: 172-181.

Echelle, A. A. (1990) In defence of the phylogenetic species concept and the ontological status of hybridogenetic taxa. Herpetologica 46: 109-113. 
Eldredge, N. (1992) Where the twain meet: causal intersections between the genealogical and ecological realms. Pp. 1-14 in N. Eldredge, ed. Systematics, ecology and the biodiversity crisis. New York: Columbia University Press.

Escalante-Pliego, B. P. (1991) Genetic differentiation in yellowthroats (Parulinae: Geothlypis). Pp. 333-341 in B. D. Bell, ed. Acta XX Congressus Internationalis Ornithologici. Wellington, N.Z.: New Zealand Ornithological Congress Trust Board.

Frost, D. R. and Hillis, D. M. (1990) Species in concept and practice: herpetological applications. Herpetologica 46: 87-104.

Galbraith, I. C. J. (1956) Variation, relationships and evolution in the Pachycephala pectoralis superspecies. Bull. Brit. Mus. (Nat. Hist.). Zool. 4: 133-222.

Hazevoet, C. J. (1989) Notes on behaviour and breeding of the Razo Lark Alauda razae. Bull. Brit. Orn. Club 109: 82-86.

Hazevoet, C. J. (1992) A review of the Santiago Purple Heron Ardea purpurea bournei, with a report of a new colony. Bird Conserv. Internatn. 2: 15-23.

Hazevoet, C. J. (1993) On the history and type specimens of the Cape Verde Cane Warbler Acrocephalus brevipennis (Keulemans, 1866) (Aves, Sylviidae). Bijdr. Dierkd. 62: 249-253.

Hazevoet, C. J. (1994a) Species concepts and systematics. Dutch Birding 16: 111-116.

Hazevoet, C. J. (1994b) Status and conservation of seabirds in the Cape Verde Islands. Pp. 279-293 in D. N. Nettleship, J. Burger and M. Gochfeld, eds. Seabirds on islands: threats, case studies and action plans. Cambridge, U.K.: BirdLife International (BirdLife Conserv. Ser. 1).

Hazevoet, C. J. (1995) The birds of the Cape Verde Islands. Tring: British Ornithologists' Union (BOU Check-list 13).

Hennig, W. (1966) Phylogenetic systematics. Urbana: University of Illinois Press.

ICBP (1992) Putting biodiversity on the map: priority areas for global conservation. Cambridge, U.K.: International Council for Bird Preservation.

James, F. C. (1983) Environmental component of morphological differentiation in birds. Science 221: 184-186.

Knox, A. (1994) Lumping and splitting of species. Brit. Birds 87: 149-159.

Lidén, M. and Oxelman, B. (1989) Species: pattern or process? Taxon 38: 228-232.

Livezey, B. C. (1990) Evolutionary morphology of flightlessness in the Auckland Islands Teal. Condor 92: 639-673.

Livezey, B. C. (1991) A phylogenetic analysis and classification of recent dabbling ducks (Tribe Anatini) based on comparative morphology. Auk 108: 471-507.

Livezey, B. C. (1995a) Phylogeny and evolutionary ecology of modern seaducks (Anatidae: Mergini). Condor 97: 233-255.

Livezey, B. C. (1995b) Phylogeny and comparative ecology of stiff-tailed ducks (Anatidae: Oxyurini). Wilson Bull. 107: 214-234.

Loope, L. L., Hamann, O. and Stone, C. P. (1988) Comparative conservation biology of oceanic archipelagoes: Hawaii and the Galápagos. BioScience 38: 272-282.

Maddison, D. R., Ruvolo, M. and Swofford, D. L. (1992) Geographic origins of human mitochondrial DNA: phylogenetic evidence from control region sequences. Syst. Biol. 41: 111-124.

Mathews, G. M. (1934) The Soft-plumaged Petrel, Pterodroma mollis, and its subspecies. Bull. Brit. Orn. Club 54: 178-179.

May, R. M. (1990) Taxonomy as destiny. Nature 347: 129-130.

Mayr, E. (1940) Speciation phenomena in birds. Amer. Nat. 74: 249-278.

Mayr, E. (1942) Systematics and the origin of species. New York: Columbia University Press

McKitrick, M. and Zink, R. M. (1988) Species concepts in ornithology. Condor 90: 1-14.

Mishler, B. D. and Brandon, R. N. (1987) Individuality, pluralism, and the phylogenetic species concept. Biol. Philos. 2: 397-414. 
Morony, J. J., Bock, W. J. and Farrand, J. (1975) Reference list of the birds of the world. New York: American Museum of Natural History.

Nelson, G. J. (1989) Cladistics and evolutionary models. Cladistics 5: 275-289.

Nelson, G. J. and Platnick, N. I. (1981) Systematics and biogeography: cladistics and vicariance. New York: Columbia University Press.

Nixon, K. C. and Wheeler, Q. D. (1990) An amplification of the phylogenetic species concept. Cladistics 6: 211-223.

O'Brien, S. J. and Mayr, E. (1991) Bureaucratic mischief: recognizing endangered species and subspecies. Science 251: 1187-1188.

O'Hara, R. J. (1993) Systematic generalization, historical fate, and the species problem. Syst. Biol. 43: 231-246.

O'Hara, R. J. (1994) Evolutionary history and the species problem. Amer. Zool. 34: 12-22.

Olson, S. L. (1994) Cranial osteology of Tawny and Steppe Eagles Aquila rapax and A. nipalensis. Bull. Brit. Orn. Club 114: 264-267.

Paterson, H. E. H. (1985) The recognition concept of species. Pp. $21-29$ in E. S. Vrba, ed. Species and speciation. Pretoria: Transvaal Museum (Transvaal Mus. Monogr. 4).

Prum, R. O. (1994) Species status of the White-fronted Manakin, Lepidothrix serena (Pipridae), with comments on conservation biology. Condor 96: 692-702.

Raikow, R. J. (1985) Problems in avian classification. Current Orn. 2: 187-212.

Remsen, J. V. (1994) Use and misuse of bird lists in community ecology and conservation. Auk 111: 225-227.

Rojas, M. (1992) The species problem and conservation: what are we protecting? Conserv. Biol. 6: $170-178$.

Salvadori, T. (1899) Collezioni ornitologiche fatte nelle isole del Capo Verde da Leonardo Fea. Ann. Mus. Civ. Stor. Nat. (Genova) (Ser. 2) 20: 283-312.

Short, L. L. (1993) The nature of species, and classification, and their importance for conservation. Pp. 11-16 in R. T. Wilson, ed. Birds and the African environment: Proceedings of the Eighth Pan-African Ornithological Congress. Tervuren: Musée Royal de l'Afrique Centrale (Ann. Mus. R. Afr. Centr. [Zool.] 268).

Sibley, C. G. and Ahlquist, J. E. (1990) Phylogeny and classification of birds. New Haven: Yale University Press.

Sibley, C. G. and Monroe, B. L. (1990) Distribution and taxonomy of birds of the world. New Haven: Yale University Press.

Siegel-Causey, D. (1988) Phylogeny of the Phalacrocoracidae. Condor 90: 885-905.

Sluys, R. (1991) Species concepts, process analysis, and the hierarchy of nature. Experientia 47: 1162-1170.

Templeton, A. R. (1989) The meaning of species and speciation: a genetic perspective. Pp. 3-27 in D. Otte and J. A. Endler, eds. Speciation and its consequences. Sunderland, Mass.: Sinauer Associates.

Tucker, G. M. and Heath, M. F. (1994) Birds in Europe: their conservation status. Cambridge, U.K.: BirdLife International (BirdLife Conserv. Ser. 3).

Zink, R. M. (1986) Patterns and evolutionary significance of geographic variation in the schistacea group of the Fox Sparrow (Passerella iliaca). Washington, D.C.: American Ornithologists' Union (Orn. Monogr. 40).

Zink, R. M. (1988) Evolution of Brown Towhees: allozymes, morphometrics and species limits. Condor 90: $7^{2-82}$.

Zink, R. M. (1994) The geography of mitochondrial DNA variation, population structure, hybridization, and species limits in the Fox Sparrow (Passerella iliaca). Evolution 48: 96111 .

Zink, R. M. and Dittmann, D. L. (1991) Evolution of Brown Towhees: mitochondrial DNA evidence. Condor 93: 98-105.

Zink, R. M. and Remsen, J. V. (1986) Evolutionary processes and patterns of geographic variation in birds. Current Orn. 4: 1-69. 
Zino, F. (1991) The Madeira Freira conservation project. World Birdwatch 13(2): 8-9.

Zino, F. and Biscoito, M. (1994) Breeding seabirds in the Madeiran archipelago, Pp. 172185 in D. N. Nettleship, J. Burger and M. Gochfeld, eds. Seabirds on islands: threats, case studies and action plans. Cambridge, U.K.: BirdLife International (BirdLife Conserv. Ser, 1).

Zino, P. A. and Zino, F. (1986) Contribution to the study of the petrels of the genus Pterodroma in the archipelago of Madeira. Bol. Mus. Mun. Funchal 38: 141-165.

\section{J. HAZEVOET}

Institute for Systematics and Population Biology, University of Amsterdam, P.O. Box 94766, 1090 GT Amsterdam, The Netherlands 